America. She stressed the importance of placing women's migration in the context of family and economic conditions. Seeking to maximize their families' economic positions, women migrated under different circumstances. Decisions to migrate were shaped by labor force segregation in the destination cities, and by the possible existence of kin or ethnic networks. Women's family roles and obligations were the key determinants of their migration decisions. Louise Tilly (New School for Social Research) urged a sensitivity to the difficulty in using "identity" as a category in historical analysis and suggested that the emerging working-class culture discussed by Locke applied to women at only one point in their life cycles. She also pointed out that varied places of origin may have had a dramatic effect on the experiences of migrant women. In her comments, Donna Gabaccia (Mercy College) stressed the importance of tying together "women adrift" and "family economy" approaches to the experiences of working-class women. She suggested that economic and cultural conditions are difficult to separate when studying immigrant women and recommended a comparative approach to the history of female migration.

These sessions revealed the need to approach working-class life with a sensitivity to the many factors mediating class experience. The sessions borrowed analytic insights from other disciplines to make sense out of working-class experiences, stepping outside rigid definitions of labor history and narrow conceptions of class. These labor historians benefit from analyses of race, gender, ethnicity, culture, and politics. Yet the various sessions were seldom talking to one another. These varied and useful approaches have eroded the unity of labor history and, while all would agree that something links the experiences of working-class people, it is difficult to blend the diverging approaches into a comprehensive understanding of working-class experience. While these papers offer rich analyses of worker life and protest, they lack an adequate theoretical tie, making sense out of what makes these different cases part of the same history, labor history.

\title{
Thirteenth Annual Meeting of the Social Science History Association
}

\author{
Ileen A. DeVault \\ NYSSILR, Cornell University
}

Sarah M. Henry

Columbia University

The thirteenth annual meeting of the Social Science History Association was held 3-6 November 1988 in Chicago. Three hundred scholars participated in eighty- 
eight panels covering a wide range of topics in the "new social history," many of which were of interest to students of working-class and labor history. The conference attracted scholars from a variety of fields and was widely praised for encouraging dialogue among the disciplines.

An early morning session on Friday entitled "Labor Organization and Revolution in the Hispanic World" presented a diverse set of papers. Robert Howard (SUNY-Stony Brook) spoke on "Change in the Nature of Labor Relations/ Labor Negotiations in an Andalusian Agro-Town from the 18th Century to the Present," comparing an eighteenth-century example of labor negotiations with an episode in the $1870 \mathrm{~s}$ in the same town. Peter Hudis, in a paper on the "Dialectics of Revolution in Bolivia, 1952-1988," argued that the coalescence of the miners' and peasants' revolts was a historically novel feature of the Bolivian revolution, not appreciated at the time and not recognized since. Finally, Theresa Deussen (University of Michigan) read "Guerrilla Warfare as the Methods of Last Resort: Guatemalan Indians and Resistance to Proletarianization." She argued that armed resistance among Guatemalan Indians was most likely where other forms of resistance, such as the organization of cooperatives, had been tried and had failed. In their comments, panel chair Renato Barhona (University of Illinois, Chicago) and Frank Safford (Northwestern University) praised the papers for taking peasant protest seriously and for examining the relationship between peasants and urban left intellectuals.

A panel on the Knights of Labor featured papers by Kim Voss (University of California, Berkeley), Sarah M. Henry (Columbia University), and W. Lawrence Neumann (University of Wisconsin, Whitewater). Voss's paper, "The Knights of Labor through a Social Movement Lens: Lessons of the Rise and Demise of America's First Mass-Based Labor Organization," concluded that few of the standard explanations for the decline of the Knights are successful, and suggested focusing attention on the role of employer associations. Henry looked at a single Knights' strike in "The Strikers and their Sympathizers: Brooklyn in the Trolley Strike of 1895," and argued that although the Knights were defeated in Brooklyn, they were successful in attracting widespread community support. Neumann spoke on "The Political Process Model and Late 19th Century Protest Movements: The Knights of Labor and Farmers Alliance," using the political process model of social movements to analyze the Knights of Labor and the Farmers Alliance as two branches of a single protest movement. Commenters Steven Rosswurm (Lake Forest College) and John Jentz both remarked on the enduring interest of the Knights as a subject of study and offered suggestions for further development of the study of the weakness and strengths of the Knights in their confrontation with the power of employers.

Friday afternoon included a panel on "The Feminine Mystique Revisited: Economic and Social Factors, Corporate and Public Policies, and Working Wives, 1950-1980," which, as panel chair Annemette Sorensen (Harvard University) 
said, analyzed three different mystiques: the mothering, the feminine, and the welfare state mystiques. Lynn Weiner (Roosevelt University) read a paper entitled "Defending 'Good Mothering': The LaLeche League and Working Mothers, 1956-1980," which described the tensions between conservatism and feminism within the League. Julia Kirk Blackwelder (University of North Carolina, Charlotte) spoke on "The 'Feminine Mystique' Revisited: Proscriptions and Women's Roles in the 1950s," disputing Friedan's thesis that the "feminine mystique" prevailed in the 1950s. In her paper, "Mothers, Workers, and Citizens: A Comparison of American and Swedish Women's Employment since 1950," Barbara Hobson (University of Chicago) analyzed women's economic dependence and differences in men's and women's work in the context of the Swedish and American welfare states. Sorensen highlighted some of the major themes in each of the papers, agreeing with Blackwelder that it is time to question Friedan, and urging Hobson to clarify and pursue her efforts to use economic dependency as a measure of gender inequality.

Weather bad enough to close Chicago's O'Hare Airport on Friday decimated the ranks of both panelists and audiences for many Saturday morning sessions. Despite this, about twenty people eventually showed up to listen to papers on "Masculinity and the Working-Class Experience." Panel chair Ava Baron (Rider College) read Mary Blewett's (University of Lowell) paper, "Manhood and the Market: The Politics of Gender and Class among the Textile Workers of Fall River, Massachusetts, 1870-1880," which demonstrated the ways in which conflicts over definitions of masculinity were deeply embedded in workers' struggles. In her paper, "Give the Boys a Trade': Gender and Job Choice in the 1890s," Ileen DeVault (Cornell University) outlined some of the ways gender considerations influenced working-class occupational choices. Walter Licht (University of Pennsylvania) and Patricia Cooper (Drexel University) provided comments that highlighted the theme of the panel: the significance for working-class history of applying gender analysis to the study of male as well as female wage earners.

Saturday morning also featured a panel on "Rural Laborers in Social and Economic Context." Stephen J. Gross (University of Minnesota) spoke on "Household Labor and the Family Life Course: The Effects of Ethnicity in NineteenthCentury Rural America," comparing the composition of the work force on Yankee, German, Irish, and Scandinavian family farms in 1900. In "Those Who Live By Wages: Agriculture and Industrial Workers in Rural Pennsylvania, 1750-1820," Lucy Simler (University of Minnesota) described how Pennsylvania farmers kept free labor in place in an established agricultural society, and how Pennsylvania "cottagers" provided the work force for the beginning of the industrial revolution. Anne Webb (Metropolitan State University) read a paper entitled "Women and Farm Labor," in which she examined the changing nature of women's farm work from 1850 to World War II. In their comments, Carville Earle (Louisiana State University) and Jeremy Atack (University of Illinois, Urbana) praised the panelists 
for looking at important issues in the history of rural labor. Both reflected on the problems of analyzing farm labor and encouraged the panelists to use the family as the unit of analysis.

An afternoon session on "Exploring Religion and Ethnicity Among WorkingClass Americans" seemed to provide a less consistent set of papers. June Granatir Alexander (University of Cincinnati) presented a paper on "The Ethnic Church as Community: The Slovak Experience," contending that Pittsburgh's fractured Slovak community united around national churches even while regionalisms persisted. On the other hand, Nora Faires's (University of Michigan, Flint) paper on "The Splintered Cross: German Sectarianism and Ideology in Pittsburgh" argued that denominational conflicts reinforced class divisions with the German immigrant community. Carole Turbin (Empire State College) discussed the ways in which women's ethnic and religious identifications influenced their attitudes about both women's rights and trade unionism in the mid-nineteenth century. Her paper, "Toward a Comprehensive Definition of Gender: Gender, Class, Ethnicity, and Religious Affiliation among 19th Century Working Women," compared the attitudes and actions of Irish collar starchers in Troy, New York, with those of native New England shoe stitchers. Deborah Dash Moore (Vassar College and YIVO Institute) brought out some of the most interesting points raised by the juxtaposition of these three papers, reminding us that internal dissension does not necessarily mean the destruction of community and calling for further attention to the spiritual and theological dimensions of ethnic churches. She also suggested that more attention be paid to the gendering of ethnic religion.

Also on Saturday afternoon, a session on "Working-Class Development in Nineteenth-Century Rural America" brought together some intriguing papers on workers whose history has often been neglected. Peter J. Way (University of Maryland, College Park) read a paper entitled "Shovel and Shamrock: Labor Violence and the Digging of North American Canals, 1780-1860," in which he traced the violent history of labor conflict over conditions on Canadian and U.S. canals. In "From Farm to Factory in the South Carolina Upcountry: The Bivingsville Manufacturing Company as a Case Study," Lawrence T. McDonnell (University of Saskatchewan) looked at the plight of those caught between farm and factory in the antebellum South. Janet Gouldner (Washington University) read a paper on "The Open Range Cowboy: From Artisan to Proletarian," tracing the disappearance of cowboys from the land. The chair of the panel, Jo Ann E. Argersinger (University of Maryland) pointed out similarities in Way's and Gouldner's approaches and praised them for looking beyond the East. Vernon Burton (University of Illinois, Urbana) stressed the importance of a careful definition of class and urged all three panelists to direct more attention to employers.

David Scobey (Brandeis University) and John Jentz read papers in a lateafternoon session entitled "Class, Politics, and the City: Chicago and New York in the Gilded Age," which was unfortunately thinly attended. Jentz spoke on "Class and Politics in Gilded Age Chicago, 1869-1875," examining class and ethnic 
conflicts and the politics of rebuilding Chicago after the Great Fire. In "The Class Politics and City Building: The Reshaping of Gilded Age New York," Scobey reflected on the relations among urban development, class development, and the debates over the growth of New York City. Richard Oestreicher (University of Pittsburgh) and David Hammack (Case Western Reserve University) highlighted the important contributions of these two papers, applauding their achievements in considering class issues in all aspects of life and their inclusion of upper and middle classes as well as the laboring classes in the study of class formation.

On Sunday morning, David Zonderman (University of Wisconsin, Madison) and Elizabeth Faue (University of Rochester) presented papers under the rubric "American Working-Class Ideology in the 19th and 20th Centuries." Zonderman's paper, "Antebellum New England Factory Operatives and Their Conception of Social Progress," discussed the range of attitudes toward industrial and technological change held by the largely female operatives. In "Gender, Labor, Iconography, and the Minneapolis Labor Movement of the 1930s," Faue described the creation by the labor press of heroic popular images that equated "labor" with violent male activity, thereby rendering invisible any organization of female workers during the same time period. In their comments, both James Barrett (University of Illinois, Urbana) and Iver Bernstein (Washington University) expounded on the possible benefits and liabilities of attempting "working-class intellectual history," with all the contradictions of "materialist" versus "idealist" that label implies. Unfortunately, there was little time left for audience discussion of the intriguing issues raised.

The last group of sessions, on late Sunday morning, included one on "The Great Decline in the Length of the Workweek," which was lively despite the tiny audience. Benjamin Hunnicutt (University of Iowa) spoke on "The New Deal and the End of Shorter Hours." He discussed the choice made in the 1920s and 1930s to stop reducing the length of the workweek and analyzed the politics of the New Deal in the context of the decision to create more work rather than to reduce hours. Robert Whaples (University of Pennsylvania) presented a paper on "The Great Decline in the Length of the Workweek and the Evolution of the Modern Labor Market." He related the changes in the labor market to the declining length of the workweek and analyzed the forces during World War I that contributed to the shorter working hours. The commentators, Richard Sutch (University of California, Berkeley) and David Roediger (University of Missouri) praised the authors for examining this unjustly ignored topic. Sutch urged both speakers to take longerrun views of their topics and to consider an international or cross-industry comparative approach. Roediger suggested that both papers could profit from considering class conflict more carefully.

These papers confront us once again with the complexity of working-class history. The phrase itself ensures that we will take class into consideration, but these papers remind us that we will not fully comprehend the meaning and significance of class without taking into account ethnicity, gender, race, religion, 
and more. Faced with the plethora of scholarship in each of these fields, we all tend to focus on one or two of these interlocking issues in our own work. We do so at our own peril. The analyses provided by each of these sets of scholarship will enrich our thinking, writing, and teaching. If we cannot read everything on every topic (and no one can any more), then we will have to be more aggressive in finding other ways of sharing our attempts to integrate these issues into our work, and more open to new angles on old topics.

\title{
Promoting Labor's Heritage of Solidarity: The Great Labor Arts Exchange
}

\author{
Michael Honey \\ Stanford Humanities Center
}

From the slave spirituals to the songs of the sit-down strikes and the labor theater of the 1930s, music and the arts have been an integral part of working people's struggles in the United States. Yet working people's efforts to organize, make a living, or resist injustices are rarely reflected by the "entertainment industry," which for the most part buries labor culture in trivial pursuits or degrading stereotypes.

A number of well-known commercial artists in recent years have begun to reassert the tradition of musical and dramatic protest, and a few have turned to labor themes. One recent example of the popular revival of the protest tradition is the Smithsonian Institution's Folkways album (jointly issued by Columbia Records), A Vision Shared, with songs of Leadbelly and Woody Guthrie performed by Sweet Honey in the Rock, Bob Dylan, Little Richard, Bruce Springsteen, U2, Willie Nelson, Emmylou Harris, Taj Mahal, John Mellencamp, Brian Wilson, Arlo Guthrie, Doc Watson, and Pete Seeger. Many more-organizers, musicians, educators, editors, union officials, actors, and working people from all walks of life-have been applying music and the arts in union struggles, on picket lines, in demonstrations, and in union halls as well as in front of university and community audiences. The use of labor's artistic and cultural traditions has been increasingly important during the 1980s as a way to counter an antilabor political culture and mind-numbing commercial entertainment with a culture of empowerment and change.

These efforts have been nurtured in recent years by a series of annual conferences where participants swap song, theater, poetry, painting, cartoons, film, and other forms of artistic endeavors. Titled "The Great Labor Arts Exchange," these meetings have been held since 1984 at the George Meany Labor Studies Center in Silver Spring, Maryland. A wide range of activists-workers 